\title{
RESEARCH ON POLICIES OF POWER BATTERIES RECYCLE IN CHINA FROM THE PERSPECTIVE OF LIFE CYCLE
}

\author{
Di WANG* \\ School of Government, Peking University, No. 5 Yiheyuan Road, Haidian District, 100871 Beijing, China
}

Received 23 October 2020; accepted 28 December 2020

\author{
Highlights \\ The life cycle diagram of power battery in China is described. \\ The development of China's power battery policy is systematically reviewed. \\ Analyze the existing policies of power battery life cycle in China. \\ Put forward policy suggestions for each link of power battery life cycle in China.
}

\begin{abstract}
As fueled by the rapid advancement of novel energies-based vehicles in our nation since 2015, Chinese production and ownership of novel energies-based vehicles in China have been leaping forward. According to $4-8$ years' service life of power batteries, China ushered into the large-scale scrapping phase of power batteries in 2019, so the power batteries recycle system should be urgently constructed. Given the life cycle perspective, the characteristics of each stage of the power battery life cycle are analyzed in the present study. As revealed from the results, the upstream end of the power batteries recycle system in China is not yet perfect, the production capacity at the midstream end tends to be excess, and the downstream end is in the exploratory phase. Moreover, the present study analyzes the policies throughout the life cycle of power batteries, and it is reported that the recycling policies at the midstream processing end are relatively concentrated, the upstream and downstream policies are comparatively deficient, the top-level legal construction is lacked, the recycling network is not perfect, and the incentive and guidance policies for echelon exploitation enterprises require modification, and relevant policy suggestions are proposed.
\end{abstract}

Keywords: power batteries, recycle policies, life cycle, environmental sustainability.

\section{Introduction}

In 2012, the State Council officially released the Development Plan for Energy-Saving and Novel energies-based vehicle Industry (2012-2020) (The State Council of the People's Republic of China, 2012). Given the content of such document, China stressed the advancement of pure Edrive cars in the future automobile industry. In 2015, with the technological progress, novel energies-based vehicles sprung up in China broadly, achieving an annual output of 345,000 . In 2016, the annual output of novel energiesbased vehicles reached 517,000, and the number of novel energies-based vehicle ownership exceeded 1 million. In 2017 and 2018, the output reached 810,000 and 1,256,000; in the meantime, the number of novel energies-based vehicle ownership in our nation exceeded 2 million. In 2020, 2 million vehicles are expected to be sold, achieving an accumulated sales volume of 5 million. Considering the battery service life of $4-8$ years, the year 2019 marks the initiation of massive scrapping of power batteries, and the scrap volume in 2019 was 12 Gwh (nearly 70,000 tons). According to the calculation of the Ministry of Industry and Information Technology, the retired power batteries in China are estimated to reach 25 Gwh (nearly 200,000 tons) in 2020 and $125 \mathrm{Gwh}(980,000$ tons) in 2025. The "scrapping" trend of power batteries has resulted in increasingly serious resource and environmental issues, and the layout of power batteries recycle industry should be urgently expedited. The raw materials of power batteries (e.g., cobalt, nickel and lithium) are less in quantity in the global scope, and they are non-renewable resources that should be recycled. Moreover, if the recycling is not taken properly, substances (e.g., heavy metals) in the waste power batteries will jeopardize the environment. Besides,

${ }^{*}$ Corresponding author. E-mail: wangdi29@pku.edu.cn 
the reasonable recycling of power batteries can exploit the power batteries that satisfy the standards in an echelon manner and expand their use value; however, the batteries that do not satisfy the standards are dismantled and recycled, in which, however, the heavy metals are of high economic value. As indicated from the calculation of the recyclable metal value of the ternary battery and the repurchase price of the lithium iron phosphate battery, the market space of dismantling and recycling of ternary batteries and echelon exploitation of lithium iron phosphate batteries in China will respectively take up 2.8 billion $\mathrm{RMB}$ and 1.4 billion RMB, totaling 4.2 billion RMB. In addition, the market space will reach 20.4 billion RMB in 2025. Since 2012, China has promulgated several policies on power batteries recycle, involving all aspects of power batteries, underpinning continuous advancement of the industry of power batteries recycle. From the perspective of life cycle, the present study analyzes each major link of the power battery as well as the policy and its role in each major link, as an attempt to provide reference for formulation and modification of Chinese polices of power batteries recycle.

\section{Literature review}

\subsection{Research on the recycling of power battery in various countries}

Back in the 1990s, the energy department of the US funded deployed a task force to conduct research on the popularization and application of electric cars. In the meantime, California started to launch "zero-emission" cars in a bid to reduce air pollution. The recycling of power battery of electric vehicles attracted plenty of attention from many scholars who focused their research on lead-acid batteries, nickel-cadmium batteries, and sodium-sulfur batteries, all of which were popularized at that time. Gaines and Singh (1995) carried out study on the energy and environmental impacts caused on the production and recycling of batteries used to power electric vehicles. The comparison between lead-acid batteries, sodium-sulfur batteries and nickel-cadmium batteries revealed that they had both merits and drawbacks, for example, though nickel-cadmium batteries consume a large amount of energy in the production process, their recycling process is more easily achievable. By conducting the study on how NI-MH batteries and lithium-ion batteries can be recycled and utilized, Jungst (1997) indicated that the fire recycling technology of nickel-metal hydride battery electronic products is applicable for both nickel-metal hydride batteries and lithium-ion batteries, despite the fact that the recycling and utilization of lithium-ion batteries remained in the phase of laboratory research. Besides, both of them can be made cost-effective through the recycling of various valuable metals contained. Apparently, the focus of attention paid to the recycling and utilization of power batteries is kept in pace with the development of electric vehicles. Nevertheless, the under-developed market hinders the amount of waste from reaching a certain scale as required, which limits it to the discussion about technical feasibility.

Recently, the constant development of electric vehicles has prompted many foreign countries to increase their efforts on the research of how to recycle and utilize power batteries, and on the evaluation of electric vehicles for the service life of power batteries. In some studies, recycling and utilization were included as the last link of the entire service life, for example, Halog, Sagisaka, and Inaba (2003) conducted LCA analysis of four power batteries used on electric vehicles for both recycling and waste disposal, including nickel-metal hydride batteries, sodiumsulfur batteries, lead-acid battery chromium, and nickel batteries. After a careful consideration given to manufacturing, social policy, and environmental impact, the analytic hierarchy process (AHP) was conducted to determine the hierarchical order, which led to the results suggesting the priority of recycling as follows: nickel-metal hydride batteries $>$ sodium-sulfur batteries $>$ lead-acid batteries $>$ nickel-chromium batteries. In the study, there were various influencing factors taken into consideration for analysis. As battery technology advances rapidly, however, the application of lithium-ion batteries has been increasingly popularized. As suggested by Van den Bossche et al. (2006), the recycling of power battery can reduce the environmental impacts caused by industrial manufacturing by as much as $50 \%$. By comparing the processing and production of batteries with both primary materials and recycled materials, Dewulf et al. (2010) drew a conclusion that the application of recycled materials is effective in reducing energy consumption by roughly $50 \%$. After evaluating the life cycle of lithium-ion batteries used in plug-in hybrid electric vehicles, Zackrisson, Avellán, and Orlenius (2010) compared and analyzed the lithium iron phosphate batteries with water and NMP as solvents, the focus of which was placed primarily on the production process of batteries. However, what was calculated was limited to the environmental impact of the transportation process at the time of recycling. Through the LCA evaluation and economical analysis conducted on three varieties of lithium-ion batteries of electric cars, including $\mathrm{LiCoO}_{2}$, lithium iron phosphate, and lithium manganese, Dunn et al. (2016) indicated that the energy consumption by different cathode materials accounted for $10-50 \%$ of the overall amount, which means the recycling of cathode materials would be conducive to significantly reducing the environmental impacts of power batteries. In the meantime, it was emphasized that the recycling conducted under moderate conditions could further improve environmental and increase economic benefits. In the study conducted by Georgiadis and Besiou (2010) on the relevant characteristics of closed-loop supply chain, a reverse logistics system dynamics model was constructed for the waste power batteries on electric vehicles, and an analysis was carried out of the impact that various influencing factors could have on the external environment and economy. According to the statistics, Väyrynen and Salminen 
(2012) suggested that the battery life could be extended by improving the recovery rate of power batteries. By conducting LCA evaluation on the lithium-ion batteries used in plug-in hybrid buses, including lithium iron phosphate battery and nickel cobalt manganese ternary lithium batteries, Olofsson and Romare (2013) obtained the results suggesting a possibility that the lithium iron phosphate batteries can have a more significant impact on the environment, which was related mainly to the production of anode materials. That is to say, the recycling conducted through a pyrogenic process or wet process could be effective in mitigating the corresponding impact. After an analysis on the sales forecast of new-energy vehicles under the impact of various social, economic, technological and ecological factors, Natkunarajah, Scharf, and Scharf (2015) conducted discussion about the service life of power batteries with different models as well as the possible service life of reusable power batteries. Ultimately, the distribution of recycling rate was determined for the lithium batteries working in different circumstances.

In general, the relevant research on power batteries started earlier, and the focus of research perspectives ranges from the amount of energy consumption, efficien$c y$, and the impact of power batteries on the environment to the assessment of its life cycle. Meanwhile, though these researches are targeted to some degree, there is still a lack of studies focusing on a specific market, especially the Chinese market.

\subsection{Research on power battery recycling in China}

Currently, there have been plenty of studies on the recycling of power batteries from various perspectives in China. For example, Zhang, Liu, and Wang (2013) conducted evaluation of the power system of electric cars and traditional vehicles for their life cycle, respectively, which led to the results suggesting that, in respect of whole life cycle, the integrated environmental impact of electric vehicle power system was about 1.6 times that of the traditional vehicles, which was attributed largely to the environmental impact partially caused in the recovery phase outweighing the environmental benefits that can be received. After conducting a life cycle evaluation on the recycling and utilization of waste lithium-ion batteries and nickelmetal hydride batteries, Gao et al. (2014) obtained the results suggesting that nickel-metal hydride batteries performed better as evidenced by most indicators of environmental impact, despite they were outperformed by lithium-ion batteries in acidification potential and human toxicity potential. Using the life cycle evaluation model, Xie et al. (2015) assessed the four industrialization processes for the preparation of ternary anode material lithium nickel-cobalt manganese, which led to the finding that the environmental index score of the directional cycle process was the lowest, followed by the traditional wet processing recovery process, traditional pyrogenic processing recovery process, and raw ore smelting process. Based on an in-depth study on the consumption layer, recycling layer processing layer and application layer of the waste battery recycling system, Zhu et al. (2015) found out that the cascade utilization of power batteries at home and abroad was still far from well-developed. It was believed that the old-fashioned batteries could be applied as energy-storing batteries, and that the batteries replaced by the energy-storing device could be decomposed and recycled, which is conducive to not only the full utilization of batteries, but also reducing the pressure placed on the recycling work by a large number of power batteries entering the recovery phase. Yao, Wang, and Huang (2015) analyzed the economical, resource and environmental benefits that can be brought by the recycling of power batteries used on electric vehicles, based on which it was proposed to adopt economic incentives and mandatory policies in combination. Besides, it was argued that the relevant authorities should formulate the laws and regulations on the recycling of power batteries used on renewable energy vehicles, develop the policies and relevant standards that apply to each link as soon as possible, as well as determine and standardize the behavior of all entities involved, so as to ensure the efficient, economical, environmental-friendly and smooth recycling of power batteries on renewable energy vehicles for China. Considering the classification of power batteries, the necessity of their recycling and the current state of power battery recycling in China, Ding (2016) analyzed the problems with the recycling of power batteries in China, from such perspectives as legislation, industry standards, the level of technological development, accountability, and government supervision. Based on the experience drawn from the US in legal framework, network system and the technology applied in the management of power battery recycling, it was suggested in this study to promote the recycling of power batteries in China by improving the relevant laws and regulations to power battery recycling, putting in place a waste battery recycling network system, building an industrywide recycling system that is premised on principles of producer responsibility, advancing the technology and process research on power battery recycling, and conducting pilot study and promotional works. Based on the life cycle, Xie et al. $(2017,2019)$ analyzed the subjects involved, which led to the finding that the enterprises engaged in dismantling end-of-life vehicles were the most important source at present, and those tiered utilization enterprises would be the most significant source in the future. Meanwhile, it was found out that the extended producer responsibility system could be applied to encode the power battery and bind it to the automobile. Further with that, it can be registered at the time of purchase by consumers, thus incentivizing consumers to give up on their old-fashioned power batteries and realizing the effective recovery of the power batteries. Through the literature review on power batteries, $\mathrm{Li}$ (2018) analyzed the existing methods and principles of design, commonly used selection models and transportation models of power batteries, which led to the design of a reverse logistics recovery 
network intended for waste power batteries. Tian et al. (2017) performed a comparative study on five typical laboratory recovery processes conducted in China by collecting the data on input materials, energy consumption, pollution emissions and final products. The environmental impact was examined from six different perspectives using the China Life Cycle Database (CLCD), and an analysis was conducted for their economic efficiency based on the Technical Cost Model (TCM) of local materials and energy market prices. It was then found out that not all innovative hydrometallurgical processes could lead to a satisfactory outcome in environmental preservation. In respect of environmental monitoring, particular attention shall be paid to indirect emissions, pollution control costs should be factored in for green profit analysis, and the recommendation of best process shall be based on the changes in the structure of social resource supply. By summarizing the significance of waste battery recycling and the approaches to it, Wang, Jiang, and Jiang (2018) proposed that, in addition to implementing the extended producer responsibility system and aligning government guidance with the market, the development of this industry could also be promoted through the waste power battery recycling and treatment foundation. Aiming at the two-dimensional uncertain language variable (TDULV) and regret theory (TDULD-RT-MULTIMOORA method), Ding and Zhong (2018) developed an extended MULTIMOORA (ratio analysis multi-objective optimization plus complete multiplication form) method that integrates the two-dimensional uncertain language variable (TDULV) with regret theory. In order to address the PBRMDM problem, an evaluation was conducted on various modes of battery recovery. As indicated by Zhang, Liu, and Song (2019), battery recycling enterprises could take advantage of the scale effect produced by its rapid development, specialist technology and network resources, to make up for the deficiency associated with the recycling mode adopted by other recycling subjects, which is more effective in meeting the demand for power battery recycling in China. Through the construction of a waste battery recycling industry chain, Jiang (2019) indicated the problems with the principle of gradient utilization in the water power batteries, for example, the difficulty in managing the residual capacity of battery, the severe blockage caused by group use, high costs, the poor performance in safety control, the unscientific setting tiered utilization, and the flawed management systems. Through a study on the recycling pricing of power battery hybrid channels for electric vehicles under government subsidies, Wang (2019) made a series of suggestions on accelerating the development of recycling system across China, including promoting the life cycle traceability management for power battery, making full use of various information channels, such as the Internet of things and big data, and ensuring the information records of power batteries through their life cycle. Zhu and Li (2020) applied Stackelberg game to study the pricing mechanism behind the dual-channel power battery recovery mode under the context of different government subsidies. Based on the sensitivity analysis and comparative analysis, the pricing decision and optimal profit of closed-loop supply chain system were indicated. Meanwhile, the impact of recycling intensity, the environmental friendliness of power battery, service level and consumers' awareness of green recycling on the price and profit of power battery was determined through numerical simulation, further with which the optimal price was compared between different strategies. Sun et al. (2020) constructed a benefit model comprised of seven parts, including environmental benefit, battery dismantling, recovery benefit, residual value and so on. With the stakeholders of power grid companies and non-power grid companies as the research objects, the economic analysis of battery recycling in Beijing was conducted in three different technological and economic circumstances, namely, optimism, business, and research. Moreover, a sensitivity analysis was also performed on both battery purchase cost (BPC) and government subsidies. According to the results, the solar panel powered by the recyclable lithium-ion batteries had a promising future in China.

Besides, some scholars conducted study on the development of laws and regulations on power batteries in China. Ding (2009) analyzed the problems with the current state of waste battery recycling in China and the reasons behind them. Particularly, the backward legislation and insufficient policy support were made mention of, and the necessity to formulate the relevant policies and regulations that make the recycling of waste batteries compulsory for citizens was emphasized. For example, Cheng (2010) analyzed the characteristics and detriments of all kinds of waste batteries, based on which it was pointed out that the legal system concerning waste battery in China was still imperfect, and that the recycling system lacks systematization. Thus, the corresponding measures were proposed to improve the recycling of waste batteries for different stakeholders such as the government, enterprises, and the public. $\mathrm{Li}, \mathrm{Wu}$, and Wang (2008) proposed to enforce a voluntary and compulsory recovery system and to put in place the security deposit system. Zhou and Zhang (2011) demonstrated the problems with current legislation by highlighting the difficulties facing the recycling of waste batteries in China, based on which the corresponding legislative measures were proposed from different perspectives for the recycling and management of waste batteries. In addition, based on the current state of waste battery recycling in China, $\mathrm{Li}$ (2010) put forward a new system of waste battery recycling in China. Liu, Cai, and Liu (2012) applied the Agent theory and multi-agent system theory to establish a recycling mode for the waste batteries from electric cars (consumers - automobile distributors - battery distributors - battery manufacturers). Then, based on the modeling and simulation experiment conducted using AnyLogic software, it was concluded that the recovery mode could be effective in reducing the demand for new batteries, cutting the waste battery production by about 
$60 \%$, and increasing the amount of battery recycling by $32.2 \%$.

Overall, the primary reason why the studies on power battery recycling in China started relatively late is that the development of electric vehicle is relatively backward in China. With the rapid development of Chinese electric vehicle industry, however, the number of relevant researches has already been on the increase in recent years, with the focus placed mainly on the use of LAC method to evaluate power battery recycling at various stages. Besides, there are a few scholars conducting study on the laws and regulations on power battery, but the focus is placed mainly on qualitative research. To sum up, despite many studies on the recycling of power batteries and a wide range of subjects, there are still few papers discussing the policies on power battery recycling in each link from the perspective of life cycle. In this paper, by analyzing the life cycle of power batteries, the power battery recycling process was elaborated on, the specific function performed by each party involved in the life cycle of power battery recycling was refined, and the existing power battery recycling policies enforced in China were incorporated into the entire life cycle of the power battery recycling, which is conducive to a more targeted analysis on the existing problems with the domestic policies on power battery recycling. Finally, some constructive suggestions were made.

\section{Life cycle of power batteries}

The concept of life cycle emerged in the 1930s, it has been met with a wide range of applications. In the field of Psychology, it refers mainly to the life cycle of people and family, in addition to meaning the process from birth, growth, aging, illness to death. In this paper, the concept of life cycle is adopted for the research on the recycling of power battery. Dealers and recycling service outlets are critical during the power battery cycle, where they are manufactured by battery manufacturers, assembled and sold to consumers by automobile enterprises, and then access into the recycling industry chain via various channels. The life cycle of power batteries is illustrated in Figure 1.

\subsection{Battery manufacturers and battery leasing enterprises}

As the front end of the whole industry chain, battery manufacturers sell the finished battery products to novel energies-based vehicle enterprises. Moreover, they sell some batteries directly to battery leasing enterprises. During the production in battery manufacturers, defective products and scrap materials will be produced. Furthermore, some of the defective batteries will be reduced to grade $B$ batteries, which will flow into the recycling service outlet together with the waste materials. After being disassembled and treated by the third-party recycling enterprises, they will access into the cathode material factories, and some of the raw materials available will reach the battery manufacturers again.

\subsection{Novel energies-based vehicle enterprises}

Novel energies-based vehicle enterprises will test the vehicles when producing and developing new models, which will produce power batteries that do not satisfy the safety standards. Besides, some novel energies-based vehicle enterprises are exploring novel marketing methods and signing power batteries recycle agreements with buyers to recycle the power batteries that reach the end of service life from the consumers in accordance with the agreement, and the mentioned batteries will flow into the recycling outlets cooperating with automobile enterprises. Accordingly, novel energies-based vehicle enterprises are one of the main sources of the scrapped power batteries as well.

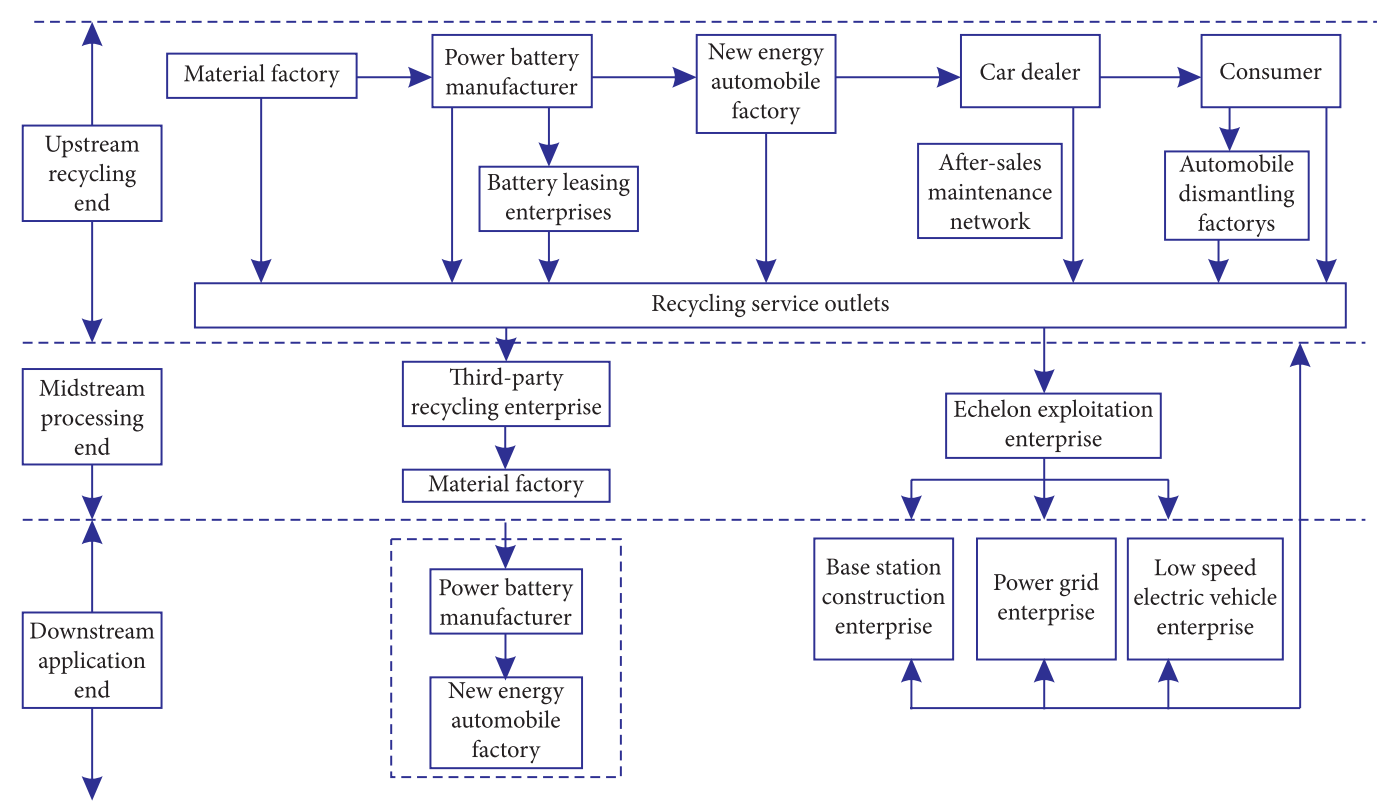

Figure 1. Power battery life cycle 


\subsection{Auto dealers}

As the transition carrier of the power batteries recycle industry chain, automobile dealers perform the functions of sales and maintenance, and they act as the main participants of power batteries recycle. First, automobile dealers sell the power batteries replaced in the maintenance to recycling service outlets or after-sales maintenance outlets, through which the batteries flow into third-party enterprises or enter echelon exploitation enterprises. This part of the dealers is more independent and difficult to control. Second, some automobile enterprises sign recycling agreements with dealers who will return the scrapped power batteries to the battery manufacturers or to the battery manufacturers through the new energy automobile plants. Such type of batteries is overall judged to have no secondary use value, so they will not flow into echelon exploitation enterprises.

\subsection{Consumers}

Since consumers own the property rights of the purchased vehicles, the property right nature will not be altered when the vehicles are scrapped. For instance, compulsory recycling of waste batteries from consumers free of charge involves the infringement of property rights. Thus, driven by property right protection and personal interests, some consumers will separate the batteries and sell them to recycling service outlets before delivering them to the scrapping and dismantling plants to gain more economic benefits.

\subsection{Enterprises for dismantling scrapped vehicles}

Scrapped vehicle dismantling enterprises act as the major channel for scrapping of waste power batteries. The core of electric vehicle scrapping and dismantling indicates the separation of power batteries from the electric vehicle. If the consumer does not disassemble the battery in advance, the electric vehicle will carry at least one set of power battery before scrapping. After being dismantled, the power battery will flow into the recycling service outlet.

\subsection{Recycling service outlets}

The recycling service outlets act as the only compliant outlet of waste power batteries in the current power batteries recycle industry chain, which satisfy a series of requirements of the Ministry of Industry and Information Technology for fire protection, safety. Their storage refers to the main outlet for most waste power batteries. After the mentioned batteries enter the recycling outlets, firstly they will be divided according to certain requirements, and then they will enter the midstream enterprises of the whole industrial chain. The power batteries recycle is commonly treated with regeneration and echelon exploitation. There is no absolute division on the recycling mode of ternary batteries and lithium iron phosphate batteries. How they are treated primarily depends on the test results of waste batteries, the benefit-cost calculation of recycling products and the characteristics of capacity attenuation. To be specific, after the batteries are tested, the used batteries exhibiting the capacity over $80 \%$ are commonly sold to the echelon exploitation enterprises, while the batteries with the capacity less than $80 \%$ are sold to the third-party recycling enterprises. In contrast, the lithium iron phosphate batteries are more suitable for echelon exploitation due to their long cycle life. However, with the increase of high nickel ternary batteries in the future, the profit of recycling will be reduced, and echelon exploitation may become the profit point of recycling enterprises. Accordingly, given the expansion of recycling sources and profit channels, most large and medium-sized recycling enterprises have both of the two recycling methods.

\subsection{Third-party recycling enterprises}

The third-party recycling enterprises directly recycle waste power batteries from the compliant recycling service outlets. Besides, though the present policy requires vehicle enterprises are required by current policies to be the major responsible party for battery recycling and capable of recycling waste batteries more efficiently, they exhibit no advantage in battery dismantling and recycling. Thus, vehicle enterprises commonly authorize battery enterprises or the third-party recycling enterprises to account for battery recycling. Afterwards, the third-party recycling enterprises disassemble the batteries. The nickel cobalt manganese lithium salt, ternary precursor and other materials flow into the material factory. Subsequently, the cathode material returns to the power battery manufacturers, thereby forming a closed-loop industrial chain. Main third-party recycling enterprises in China consist of GEM, BRUNP, Ganzhou Highpower, Fangyuan Environmental Protection, etc. With the arrival of "scrapping tide" of power batteries, the production capacity of power batteries recycle enterprises is booming, and there is already a sign of overcapacity.

\subsection{Echelon exploitation enterprises}

Echelon exploitation enterprises are the secondary exploitation units for power batteries recycle, which increases the exploitation times of power battery life cycle, elevates the resource exploitation rate, and then delays the arrival of the scrapping tide of power batteries. At present, there are four main directions for echelon exploitation enterprises to recycle and restructure the power batteries: (1) large scale energy storage. It is employed to serve MV level energies storing mechanism at the generation side/ the user side, for peak load shifting and grid connection of renewable energy. The merit lies in that the performance of the recycled power battery is close to that of the novel lithium battery, and the cost is consistent with that of the lead-carbon battery. A typical case is the 10 MV echelon exploitation energy storage power station delivered by Jiangsu Changzhou New Energy Co., Ltd. in 
the High-tech Zone, Wujin District, Changzhou City. (2) Home energy storage. It is employed for power expansion and peak load shifting. The advantage indicates that the energy of a single battery pack is nearly 20 degrees, applying to the whole package application, and the bidirectional PCS and energy management system are presented. Nissan and Sumitomo cooperated and jointly invested to found the $4 \mathrm{R}$ Energy company, i.e., a highly representative example. (3) Base station energy storage. It is adopted for standby power supply of base station, acting as the alternative of lead-acid battery solution. As compared with the lead-acid battery, it exhibits higher cost performance and gradually becomes the alternative. The classic case is that China Tower Corporation uses $2 \mathrm{GWh}$ of echelon batteries (battery amount of 50,000 electric vehicles) in 20,000 base stations across the country, which is the most mature echelon exploitation scenario of power batteries. (4) Low speed electric drive. It is used for the power source of electric vehicles, and low-speed electric power station operation. The merits are elucidated that with the introduction of novel national standards, the low-speed electric drive market become standardized, it turns out to be a trend to replace the lead-acid batteries, and the industry potential is substantial. The typical case is that Zhejiang Electric Power Corporation of the State Grid reorganizes the retired power batteries of electric vehicles for the power supply of $48 \mathrm{~V}$ electric bicycles. Besides, Zhongtian Hongli has cooperated with Qingdao SF Express and Guangzhou JD Logistics for echelon batteries of express electric tricycles for leasing instead of sales and power station operation. On the whole, the business model of echelon exploitation is still in the exploratory phase at present. Due to the lack of consistency of retired battery packs, the detection and screening are difficult and the cost is high. Though the theoretical cost performance of echelon batteries outperforms that of lead-acid, lead-carbon and new lithium batteries, their actual promotion faces challenges. The echelon exploitation is still in the experimental and demonstration application stage.

On the whole, (1) the upstream recycling end (e.g., novel energies-based vehicle plants, dealers, consumers, scrapped vehicle dismantling plants, and recycling service outlets) remains being explored initially. As guided by policies, regular recycling channels are gradually forming. The recycle outlets satisfying the requiring points of the Ministry of Industry and Information Technology for fire protection, safety, storage and other aspects act as the only compliant outlets for waste power batteries. Indeed, the existing outlets should be reformed or constructed jointly by multiple parties. The existing raw materials of recycling enterprises remain primarily $3 \mathrm{C}$ batteries, scrap materials from material factories/battery factories and imported metal intermediate products. (2) The midstream processing end (e.g., the third-party recycling enterprises and echelon exploitation enterprises) owns mature recycling technologies. The power battery recovery capacity is in the expansion stage, with regional overcapacity.
Environmental protection will become the main factor limiting the capacity expansion. Recycling enterprises start to arrange the echelon exploitation. The vehicle factory, the material plant and Iron Tower Corporation are currently exploring the echelon exploitation business model via joint venture or establishment of subsidiaries. (3) The downstream application end (e.g., base station construction enterprises, power grid enterprises and low-speed electric vehicle enterprises) exhibits a high concentration, and the demand for ternary cathode materials and precursors has been on steady increase. The largest demand for echelon exploitation originates from communication base stations. There are demonstration projects or regional projects for grid energy storage and low-speed electric drive, which are being further explored.

\section{Current situation of power batteries recycle political arguments in China}

\subsection{Power batteries recycle political arguments in China}

In 2012, China officially promulgated the Developing Plans for Energy Saving and Novel energies-based vehicle Industry. Ever since then, the novel energies-based vehicles growing in number in the whole society have begun to be of critical importance, and the nation has stressed the development of novel energies-based vehicles. It is noteworthy that novel policies have been promulgated in the battery recycling. China has currently made it clear that the responsibility system of battery manufacturers is primarily adopted for battery recycling, as an attempt to strengthen the recycling of waste batteries and constantly optimize and standardize the battery recycling industry (Zhang \& $\mathrm{Wu}, 2018)$. Some relevant regulations and policies and industry standards on battery recycling introduced in China over the past few years are listed in Table 1.

\subsection{Analysis of life cycle policies on power batteries recycle in China}

From the perspective of life cycle and recycling industry chain, the battery life cycle is summarized into five stages: design, production, sales, maintenance (replacement) and recycling. The recycling stage can be divided into upstream recycling end, midstream processing end and downstream application end. The policies designed in each part are divided into guiding policies and restrictive policies, and the policy number is marked in the corresponding link, as illustrated in Figure 2.

\subsubsection{Power battery design}

For the power battery design, currently the policies are mostly focused on the restrictive policies. For instance, the battery design and coding are specified in Code of Automotive Power Batteries and Specification and Dimension of Power Batteries for Electric Vehicles (Draft). Moreover, the Interim Measures for Power batteries recycle of Novel 
Table 1. Policies and industry standards on battery recycling in China

\begin{tabular}{|c|c|c|}
\hline No. & Date & Regulations and Policies \\
\hline 1 & $\begin{array}{l}\text { July, } \\
2012\end{array}$ & $\begin{array}{l}\text { As revealed from the content of Development Plan for Energy Saving and Novel energies-based vehicle Industry } \\
(2012-2020) \text { (The State Council of the People's Republic of China, 2012), the relevant departments should stress } \\
\text { power battery recycle, strengthen the management, formulate and improve the management plan, and build a good } \\
\text { management system to improve its recycling rate. Moreover, it is necessary to strengthen the encouragement and } \\
\text { guidance for relevant enterprises, support enterprises to vigorously recycle batteries, as an attempt to improve the } \\
\text { battery recycling rate. Moreover, access conditions should be improved, and enterprises that do not satisfy the } \\
\text { standard are not allowed to launch power batteries recycle. }\end{array}$ \\
\hline 2 & $\begin{array}{l}\text { July, } \\
2014\end{array}$ & $\begin{array}{l}\text { Given the Guidelines of the General Office of the State Council for Expediting Novel energies-based vehicle Promotion } \\
\text { and Application (The State Council of the People's Republic of China, 2014), in the following development process, } \\
\text { it is necessary to further modify the current laws, regulations and policies, and develop more diversified ways to } \\
\text { recycle the mentioned batteries (e.g., mandatory recycling and fund recycling) as an attempt to build an improved } \\
\text { power battery exploitation system. }\end{array}$ \\
\hline 3 & $\begin{array}{l}\text { March, } \\
2015\end{array}$ & $\begin{array}{l}\text { In accordance with Industry Standard Conditions for Automotive Power Batteries (Ministry of Industry and } \\
\text { Information Technology of the People's Republic of China, 2015), automobile enterprises and power batteries recycle } \\
\text { system enterprises should cooperate and contact each other to develop a systematic and complete waste power } \\
\text { batteries recycle system. }\end{array}$ \\
\hline 4 & $\begin{array}{l}\text { Ja- } \\
\text { nuary, } \\
2016\end{array}$ & $\begin{array}{l}\text { It is highlighted in Policies on Recycling Technologies for Electric Vehicle Power Batteries (2015 edition) (National } \\
\text { Development and Reform Commission of the People's Republic of China, 2016) that the battery recycling rate has } \\
\text { to be further enhanced, and a coding system has to be built, as an attempt to ensure that every used battery can be } \\
\text { traced back to the source. It is also mentioned that the broadened producer responsible mechanism should be used. } \\
\text { Moreover, the recycling technology should be ensured to be feasible, which does not adversely affect the economy; } \\
\text { besides, safety should be ensured, which underpins practice. }\end{array}$ \\
\hline 5 & $\begin{array}{l}\text { Feb- } \\
\text { ruary, } \\
2016\end{array}$ & $\begin{array}{l}\text { As highlighted in Industry Standard Conditions for Overall Exploitation of Waste Power Batteries of Novel energies- } \\
\text { based vehicles (Ministry of Industry and Information Technology of the People's Republic of China, 2016a), more } \\
\text { optimized and advanced facilities should be used to recycle waste power batteries. New technologies of energy saving, } \\
\text { environmental protection, cleaning and high efficiency should be adopted, and the process exhibiting high energy } \\
\text { consumption and heavy pollution should be eliminated. Overall use of physical and chemical methods is encouraged } \\
\text { and bio-metallurgy should be explored. Enterprises should strictly follow the principle of echelon exploitation before } \\
\text { recycling, proactively launch the R\&D and application of resource recycling technologies and equipment for anode } \\
\text { and cathode materials, diaphragms and electrolytes, and strive to elevate the recycling level of relevant elements, } \\
\text { reduce overall energy consumption and improve energy exploitation efficiency. }\end{array}$ \\
\hline 6 & $\begin{array}{l}\text { Feb- } \\
\text { ruary, } \\
2016\end{array}$ & $\begin{array}{l}\text { It is highlighted in Interim Measures for Management of Industry Standard Announcement for Overall Exploitation } \\
\text { of Waste Power Batteries of Novel energies-based vehicles (Ministry of Industry and Information Technology of the } \\
\text { People's Republic of China, 2016b) that it is necessary to further promote the development of overall exploitation } \\
\text { industry of waste power batteries of novel energies-based vehicles, strengthen the management and supervision of } \\
\text { the industry, promote the standardization of its development and enhance the exploitation rate. }\end{array}$ \\
\hline 7 & $\begin{array}{l}\text { Feb- } \\
\text { ruary, } \\
2016\end{array}$ & $\begin{array}{l}\text { It is highlighted in Policies on Prevention and Control Technology for Waste Battery Pollution (Draft) (Ministry of } \\
\text { Ecology and Environment of the People's Republic of China, 2016) to expand the scope of waste batteries. Besides the } \\
\text { previous batteries, three new types are introduced: firstly, solar cells; second, new lithium batteries; thirdly, fuel cells. } \\
\text { Specific ways and management measures of recycling waste batteries are put forward. R\&D of complete set of reverse } \\
\text { dismantling equipment for lithium-ion batteries, power batteries and energy storage batteries, and new technologies } \\
\text { for lithium battery separators, metal products and motor material recycling treatment equipment are encouraged. }\end{array}$ \\
\hline 8 & $\begin{array}{l}\text { Octo- } \\
\text { ber, } \\
2016\end{array}$ & $\begin{array}{l}\text { To boost the development of power batteries in depth, make its development more orderly and large-scale, facilitate } \\
\text { the life cycle traceability management, and deepen the healthy and sustaining advancement of the power battery } \\
\text { industry, the code and size of power batteries are specified in Code of Automotive Power Batteries and Specification } \\
\text { and Dimension of Power Batteries for Electric Vehicles (Draft) (General Administration of Quality Supervision, } \\
\text { Inspection and Quarantine of the People's Republic of China, 2016a, 2016b). }\end{array}$ \\
\hline 9 & \begin{tabular}{l|} 
Decem- \\
ber, \\
2016
\end{tabular} & $\begin{array}{l}\text { It is highlighted in the Interim Measures for Power batteries recycle of Novel energies-based vehicles (Draft) (Ministry } \\
\text { of Industry and Information Technology of the People's Republic of China, 2016c) that in the management process, } \\
\text { it is necessary to highlight the responsibility subject, fully roll out the producer responsibility system, investigate the } \\
\text { market-directed pattern of power batteries recycle, and encourage the echelon exploitation of power battery. }\end{array}$ \\
\hline 10 & $\begin{array}{l}\text { Ja- } \\
\text { nuary, } \\
2017\end{array}$ & $\begin{array}{l}\text { It is highlighted in Implementation Plan for Broaden Producer Responsible Mechanism (General Office of the State } \\
\text { Council of the People's Republic of China, 2017) that the producer responsibility should be further extended, which } \\
\text { largely includes four aspects. Firstly, the scope of information disclosure should be further promoted. Second, } \\
\text { ecological design should be conducted. Thirdly, the standardization of recycling should be further improved. Fourthly, } \\
\text { renewable materials should be used as much as possible. }\end{array}$ \\
\hline 11 & $\begin{array}{l}\text { May, } \\
2017\end{array}$ & $\begin{array}{l}\text { It is highlighted in Specification for Recycling and Dismantling of Automotive Power Batteries (General Administration } \\
\text { of Quality Supervision, Inspection and Quarantine of the People's Republic of China, 2017a) that when dismantling } \\
\text { waste power batteries, the following principles should be followed: firstly, safety principle; second resource recycling } \\
\text { principle; and lastly, environmental protection principle. The main process of disassembly includes four steps: firstly, } \\
\text { the pretreatment of disassembly; second, disassembly of the battery pack; thirdly, disassembly of the battery module; } \\
\text { fourthly, to get the battery cell. }\end{array}$ \\
\hline
\end{tabular}




\begin{tabular}{|c|c|c|}
\hline No. & Date & Regulations and Policies \\
\hline 12 & & $\begin{array}{l}\text { It is highlighted in Detection of Residual Energy of Automotive Power batteries recycle (General Administration of } \\
\text { Quality Supervision, Inspection and Quarantine of the People's Republic of China, 2017b) that during vehicle power } \\
\text { batteries and energy detection, the main steps include: inspection of its appearance, collection of main information, } \\
\text { judgment of voltage, determination of the first current charging and discharging, determination of 5h rate discharge } \\
\text { current and material identification, residual energy detection. }\end{array}$ \\
\hline 13 & $\begin{array}{l}\text { July, } \\
2017\end{array}$ & $\begin{array}{l}\text { The Coding Rules for Automotive Power Batteries (General Administration of Quality Supervision, Inspection and } \\
\text { Quarantine of the People's Republic of China, 2017c) specifies the coding of power batteries in detail. }\end{array}$ \\
\hline 14 & $\begin{array}{l}\text { Ja- } \\
\text { nuary, } \\
2018\end{array}$ & $\begin{array}{l}\text { It is highlighted in the Interim Measures for Management of Power batteries recycle of Novel energies-based vehicles } \\
\text { (Ministry of Industry and Information Technology of the People's Republic of China, 2018a), the hazardous materials } \\
\text { used by power battery manufacturers should satisfy the requirements of relevant national standards, and renewable } \\
\text { materials should be used as far as possible. Battery production enterprises are encouraged to cooperate with overall } \\
\text { exploitation enterprises, and launch multi-level and multi-purpose rational exploitation according to the principle } \\
\text { of echelon exploitation before recycling, as an attempt to reduce overall energy consumption, increase energy } \\
\text { exploitation efficiency, improve overall exploitation level and economic benefits, and ensure the environmental- } \\
\text { friendly disposal of unusable residues. The Ministry of Industry and Information Technology, together with the } \\
\text { national standardization department, studies and formulates the technical standards for power batteries recycle, while } \\
\text { developing a standard system for power batteries recycle and management. }\end{array}$ \\
\hline 15 & $\begin{array}{l}\text { March, } \\
2018\end{array}$ & $\begin{array}{l}\text { It is highlighted in the Implementation Plan for Pilot Projects of Power batteries recycle of Novel energies-based vehicles } \\
\text { (Ministry of Industry and Information Technology of the People's Republic of China, 2018b) that for the following } \\
\text { areas (e.g., the Pearl River Delta, Beijing-Tianjin-Hebei, the Yangtze River Delta), in the pilot course of power } \\
\text { batteries recycle, regions should be selected reasonably to ensure that the selected regions have a strong driving } \\
\text { force, which can be applied to power battery recycle. The recycling system should be built and improved, a variety } \\
\text { of business models should be built, the technology use should be enhanced, and a systematic and improved incentive } \\
\text { system should be set up. }\end{array}$ \\
\hline 16 & & $\begin{array}{l}\text { The technology innovation alliance for compulsory resource recycling industry issued five group standards, i.e., } \\
\text { General Production Requirements for Overall Exploitation Enterprises of Waste Power Batteries, Technical Specifications } \\
\text { for Wet Recovery of Lithium in Waste Lithium-ion Batteries, Crude Cobalt Nickel Solution, Crude Nickel Sulfate Solution, } \\
\text { and Industrial Molybdic Acid (Alliance of Technological Innovation in Compulsory Resources Recycling Industry, } \\
\text { 2018), specifying the basic requirements and management requirements for overall exploitation enterprises of waste } \\
\text { power batteries, safety and environmental protection requirements. }\end{array}$ \\
\hline 17 & $\begin{array}{l}\text { July, } \\
2018\end{array}$ & $\begin{array}{l}\text { Requirements for Recycling Materials for Automotive Power Batteries (Draft) (General Administration of Quality } \\
\text { Supervision, Inspection and Quarantine of the People's Republic of China, 2018) specifies the general requirements, } \\
\text { personnel operation requirements, site requirements and treatment technical requirements for the recycling of } \\
\text { recycling enterprises and factories, and proposes the recovery rate and calculation method. }\end{array}$ \\
\hline 18 & $\begin{array}{l}\text { July, } \\
2018\end{array}$ & $\begin{array}{l}\text { It is highlighted in Interim Provisions on Traceability Management of Power batteries recycle of Novel energies-based } \\
\text { vehicles (Ministry of Industry and Information Technology of the People's Republic of China, 2018c) that to increase } \\
\text { the efficiency of power batteries recycle, information collection should be conducted for all links, monitoring and } \\
\text { management of each link should be strengthened, and an optimized information management platform should be } \\
\text { built. }\end{array}$ \\
\hline 19 & $\begin{array}{l}\text { Ja- } \\
\text { nuary, } \\
2019\end{array}$ & $\begin{array}{l}\text { The proposed Discharge Specifications for Automotive Power batteries recycle (Ministry of Industry and Information } \\
\text { Technology of the People's Republic of China, 2019a) specifies the general requirements for the discharge specification } \\
\text { for automotive power batteries recycle, which consist of the general requirements, facilities and equipment } \\
\text { requirements, as well as presentation requirements. }\end{array}$ \\
\hline 20 & $\begin{array}{l}\text { Ja- } \\
\text { nuary, } \\
2019\end{array}$ & $\begin{array}{l}\text { The proposed Automotive Power batteries recycle and Echelon exploitation Product Identification (Ministry of Industry } \\
\text { and Information Technology of the People's Republic of China, 2019b) specifies the requirements for echelon } \\
\text { exploitation products and the general requirements for enterprises, as well as the specification requirements for } \\
\text { echelon exploitation product identification. }\end{array}$ \\
\hline 21 & $\begin{array}{l}\text { Ja- } \\
\text { nuary, } \\
2019\end{array}$ & $\begin{array}{l}\text { Guideline for Construction and Operation of Recycling Service Outlets of Power Batteries of Novel energies-based vehicles } \\
\text { (Draft) (Ministry of Industry and Information Technology of the People's Republic of China, 2019c) elucidated the } \\
\text { following specific requirements. Firstly, recycling service outlets for waste power batteries and echelon exploitation } \\
\text { should be constructed for novel energies-based vehicles, the role of the mentioned batteries, environmental protection } \\
\text { requirements. }\end{array}$ \\
\hline 22 & $\begin{array}{l}\text { Ja- } \\
\text { nuary, } \\
2020\end{array}$ & $\begin{array}{l}\text { It is highlighted in Industry Standard Conditions for Overall Exploitation of Waste Power Batteries of Novel energies- } \\
\text { based vehicles (2019 version) (Ministry of Industry and Information Technology of the People's Republic of China, } \\
\text { 2020) and Interim Measures for Industry Standard Announcement Management of Overall Exploitation of Waste Power } \\
\text { Batteries of Novel energies-based vehicles (2019 version) (Ministry of Industry and Information Technology of the } \\
\text { People's Republic of China, 2019d) that during the recycling of waste batteries, information traceability should be } \\
\text { provided, and well-developed equipment and infrastructure should be built. The standards and systems formulated by } \\
\text { the state should be observed and the overall exploitation capacity should be enhanced. In addition, it is highlighted } \\
\text { in the Standard Conditions that in enterprises, it is necessary to build a more systematic and overall management } \\
\text { system, strengthen the monitoring of each link, build a database for the information and data obtained from all links, } \\
\text { and adopt more developed technology to improve the level of information. }\end{array}$ \\
\hline
\end{tabular}




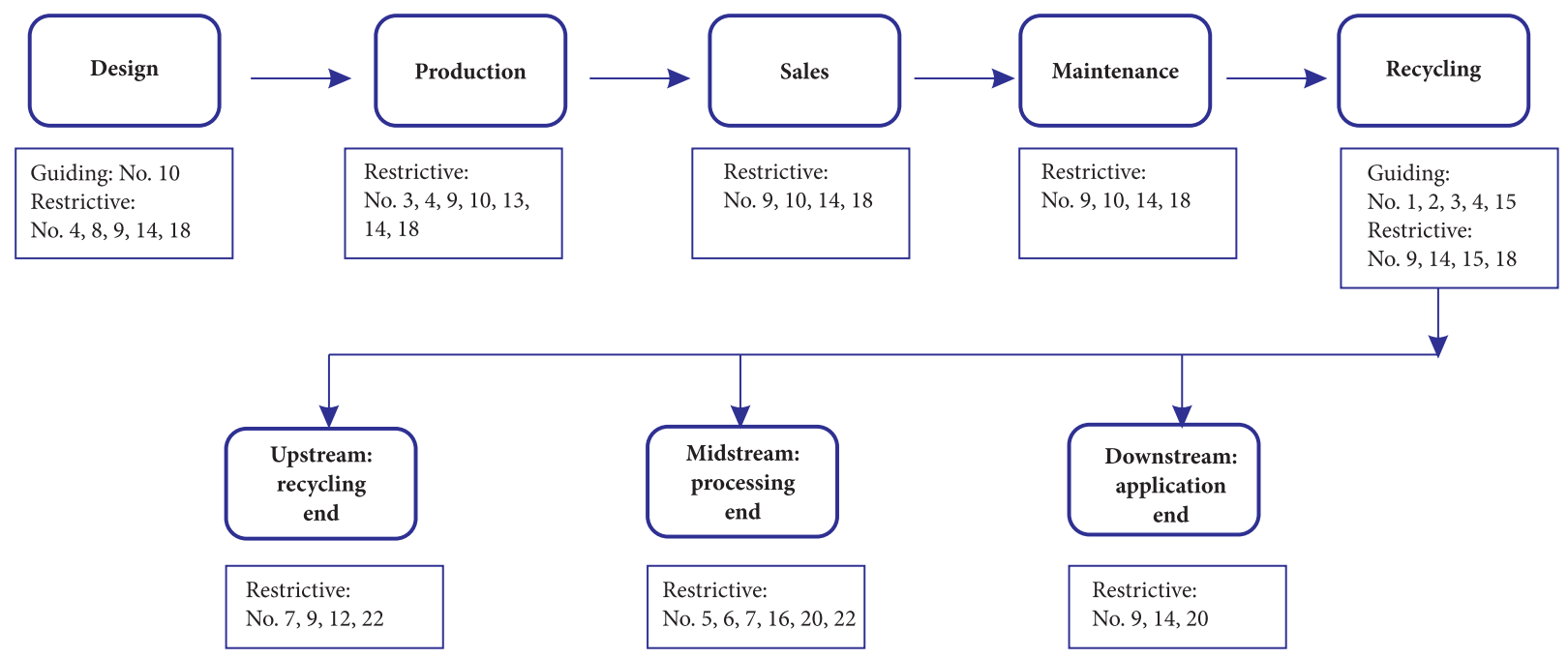

Figure 2. Life cycle policies for power batteries recycle

energies-based vehicles (Draft) specifies the standardization, universality and easy disassembly structure design of power batteries. In addition, the Implementation Plan for Broaden Producer Responsible Mechanism also highlighted that the resource and environmental responsibilities of producers should be further expanded. Besides the production link, it should also be extended to all other links, involving all cycles, and the guidance for battery design should be strengthened.

\subsubsection{Power battery production}

Power battery production is an important link in the life cycle of power batteries, which involves many attributes (e.g., coding, size, environmental protection and economy). The existing policies in this regard are primarily restrictive policies. For instance, the Industry Standard Conditions for Automotive Power Batteries and Policies on Recycling Technologies for Electric Vehicle Power Batteries (2015 edition) proposed specific requirements for a range of aspects of power battery manufacturers, constating of the location, production capacity, process, safety, environmental protection, research, as well as development. Moreover, enterprises are encouraged to jointly develop and share the recycling network for waste power batteries through entrusted agents or cooperation with recycling enterprises. Furthermore, similar to the power battery design, relevant policies stipulate the battery size, code and manufacturer extension system. In addition, the Plan for Implementing Broaden Producer Responsible Mechanism requires battery manufacturers to broaden their responsibility in terms of resource and environment in the producing link to the entire product design cycle, circulation and consuming process, recycle and waste disposing process, and proposes specific requirements for launching ecological design, exploiting renewable raw materials, standardizing recycling and optimizing information disclosure.

\subsubsection{Power battery sales}

According to relevant policies at present, there are more restrictive policies in the power battery selling. For instance, Interim Measures for Management of Power batteries recycle of Novel energies-based vehicles and Interim Provisions on Traceability Management of Power batteries recycle of Novel energies-based vehicles elucidated that for all novel energies-based vehicles, their information and the information of owners should be uploaded in detail. In the user's manual, the specific situation and process of battery recycling are highlighted in detail, and all public service outlets are shown, and the information of these outlets is described.

\subsubsection{Power battery maintenance}

The maintenance stage of power batteries is similar to the sales stage, and the serval policies are primarily restrictive policies. Interim Measures for Management of Power batteries recycle of Novel energies-based vehicles and Interim Provisions on Traceability Management of Power batteries recycle of Novel energies-based vehicles put forward that a maintenance service network should be built, technical information e.g., maintenance and replacement of power batteries should be disclosed, information of novel energies-based vehicles and owners should be checked during maintenance, disassembly and replacement, and waste power batteries should be transferred to recycling services outlets rather than other units or individuals, and the dynamic connection between batteries and vehicles should be recorded in the traceability information system.

\subsubsection{Power batteries recycle}

Power batteries recycle is an important link in the life cycle of power batteries, and also a link with relatively concentrated policies. According to their characteristics, the power batteries recycle is divided into upstream recycling 
end, midstream processing end and downstream application end. Some guiding policies also highlighted the complete recycling link. For instance, Development Plan for Energy-Saving and Novel energies-based vehicle Industry (2012-2020), Guidelines of the General Office of the State Council for Accelerating the Promotion and Application of Novel energies-based vehicles, Industry Standard Conditions for Automotive Power Batteries, Policies on Recycling Technologies for Electric Vehicle Power Batteries (2015 Edition) and Implementation Plan for Pilot Projects of Power batteries recycle of Novel energies-based vehicles have guided and encouraged each link of electric vehicle recycling in power batteries recycle system, battery deposit system, cooperation between recycling enterprises and automobile enterprises, as well as construction of pilot projects of power batteries recycle. For restrictive policies, the most representative policy is recognized as the Interim Measures for Management of Power batteries recycle of Novel energiesbased vehicles, which highlighted relevant processes and details of the respective link (e.g., echelon exploitation, power batteries recycle outlets).

(1) Upstream recycling end

The upstream recycling end largely indicates the recycling outlets and their material sources that satisfy the requirements of the Ministry of Industry and Information Technology for fire protection, safety and storage, mostly consisting of recycling outlets, material factories, battery manufacturers, consumers, commercial vehicle enterprises, automobile dealers, battery leasing enterprises, aftersales maintenance outlets, as well as scrapped automobile dismantling plants. At present, most of the policies are restrictive, and few refer to guiding policies. From the latter perspective, Guidelines of the General Office of the State Council for Accelerating the Promotion and Application of Novel energies-based vehicles highlighted that during recycling of waste power batteries, diversified methods should be adopted (e.g., deposit and compulsory recycling). Policies on Recycling Technologies for Electric Vehicle Power Batteries (2015 Edition) also highlighted that if the internal business of an enterprise contains battery production, it is required to develop a complete battery recycling system, and enterprises should strengthen cooperation and contact, jointly construct recycling network, and facilitate information sharing and transmission. Other policies are primarily restrictive. For instance, the Policies on Prevention and Control Technology for Waste Battery Pollution has specific requirements for the classification of batteries and heavy metals during waste battery collection. One of the most representative documents is recognized as Guideline for Construction and Operation of Recycling Service Outlets of Power Batteries of Novel energies-based vehicles (Draft), officially issued in 2019. The document also elucidated some relevant requirements of different links (e.g., information disclosure, information collection and network layout).

(2) Midstream processing end

The midstream processing end largely consists of the third-party recycling enterprises and echelon exploitation enterprises. The existing relevant policies for such type of enterprises refer to restrictive policies. For instance, the Policies on Recycling Technologies for Electric Vehicle Power Batteries (2015 Edition) raised the relevant requirements for the disassembly, storage, transportation and discharge of automotive power batteries at the recycling end, and the exploitation principle, echelon exploitation specification, recycling specification, pyrolysis, crushing and separation, smelting and other specific links at the exploitation end. Second, the technology innovation alliance for compulsory resource recycling industry issued five group standards, consisting of the General Production Requirements for Overall Exploitation Enterprises of Waste Power Batteries, in which the basic requirements, management requirements and safety and environmental protection requirements for power battery overall exploitation enterprises are raised. In addition, there are also many policies that indicate what conditions can be satisfied for the recycling and exploitation of the mentioned batteries, mostly covering the Interim Measures for Management of Industry Standard Announcement for Overall Exploitation of Waste Power Batteries of Novel energies-based vehicles (2019 version) and Industry Standard Conditions for Overall Exploitation of Waste Power Batteries of Novel energies-based vehicles (2019 version). Lastly, some documents also specify corresponding requirements and conditions for different links in the whole recycling (e.g., technical requirements, environmental protection requirements and site selection requirements), which involve the Industry Standard Conditions for Overall Exploitation of Waste Power Batteries of Novel energies-based vehicles (2019 version) and Interim Measures for Industry Standard Announcement Management of Overall Exploitation of Waste Power Batteries of Novel energies-based vehicles (2019 version). Abiding by such industrial policies, there are also policies specifying the specific implementation details (e.g., Policies on Prevention and Control Technology for Waste Battery Pollution (Draft) and Specification for Recycling and Dismantling of Automotive Power Batteries).

(3) Downstream application end

Novel energies-based vehicle plants, battery plants and others all fall into the downstream application end of recycling. From the perspective of guiding policies, Development Plan for Energy Saving and Novel energiesbased vehicle Industry (2012-2020) highlighted that to further improve the recycling efficiency of waste batteries, it is necessary to build a complete system and stipulate the rights, responsibilities and obligations of different subjects. From the perspective of restrictive policies, the Policies on Recycling Technologies for Electric Vehicle Power Batteries (2015 Edition) highlighted that when using the mentioned batteries, one of the main principles to be followed is echelon exploitation before recycling, as an attempt to enhance the resource exploitation rate. The main content of the Interim Measures for Power batteries recycle of Novel energies-based vehicles (Draft) and the Interim Measures for Management of Power batteries recycle of Novel energies-based vehicles consists of the 
requirements for the use of batteries, enterprises producing and using batteries, etc. The Automotive Power batteries recycle and Echelon exploitation Product Identification defines the product requirements and general requirements for echelon exploitation enterprises.

On this basis, the seven ministries and commissions jointly issued the Implementation Plan for Pilot Projects of Power batteries recycle of Novel energies-based vehicles in March 2018, which highlighted that for the regions like the Pearl River Delta, Beijing-Tianjin-Hebei and the Yangtze River Delta, when carrying out the pilot work of power batteries recycle, reasonable selection of regions should be made to ensure that the selected regions have a strong driving force and can be applied to recycling of power batteries. The recycling system should be built and improved, a variety of business models should be built, the technology use should be enhanced, and a systematic and complete incentive system should be constructed. Subsequently, Beijing, Tianjin, Hebei, Zhejiang, Inner Mongolia, Anhui, Fujian, Heilongjiang, Shanxi, Yunnan, Guangdong, Guangxi, Sichuan, Hunan, Shandong and other provinces and cities successively launched relevant plans and schemes, which put forward requirements for the design, production, sales and recycling of power batteries of novel energies-based vehicles. Most of the regional policies are primarily aimed at the design, production and sales of power batteries, and largely are guiding and encouragement policies.

\subsection{Policy summary}

For the life cycle of power batteries recycle, existing relevant Chinese policies basically cover the whole life cycle of power batteries. Relatively speaking, most of the policies focus on the design, production and recycling of power batteries, especially the policies for the midstream processing end of recycling; there are fewer policies for the sales and maintenance stages, i.e., mostly restrictive policies. In addition, several policy documents raise the requirements for almost each link of the automotive power batteries (e.g., production, maintenance and design). For instance, Implementation Plan for Broaden Producer Responsible Mechanism, Interim Measures for Management of Power batteries recycle of Novel energiesbased vehicles and Interim Provisions on Traceability Management of Power batteries recycle of Novel energiesbased vehicles. However, it has also been found out that despite some policies designed for each link in the life cycle of power battery, it has been less than one decade since the initial relevant policies were issued in China due to the late development of electric vehicles. Besides, the policies are targeted at a specific link, which means a lack of the top-level design. In particular, the network of power battery recycling and related links of step utilization are still underdeveloped. Therefore, China is still lagging behind some developed countries in the power battery recycling policies.

\section{Problems with policies on power batteries recycle}

\subsection{Imperfect top level regulations}

At present, some developed nations, having achieved an early start of automobile industry and by drawing upon their years of operation and exploration, have built a network system for power batteries recycle, with corresponding legal support. For instance, the United States promulgated the Mercury-Containing and Rechargeable Battery Management Act and the Rechargeable Battery Recycling Act (Ding, 2016). Germany issued the Battery Recycling Act as well (Li \& Gao, 2013). The electric vehicle industry in China had a relatively late start, and electric vehicle related policies are being introduced, especially the recycling network system for electric vehicle power batteries remaining being explored. The existing policies and regulations are primarily issued by the Ministry of Industry and Information Technology, there is no separate law for power batteries recycle, and there are insufficient laws and regulations for the power batteries recycle market.

\subsection{Imperfect recycling network}

As suggested by the summary and policy analysis of the power batteries recycle end, the recycling end is being initially explored, the regular recycling channels are progressively formed as guided by policies. At present, the recycling service outlets that satisfy the requirements of the Ministry of Industry and Information Technology are the compliant outlet of the waste power batteries. several policies have mentioned the construction of the recycling end, which covers the establishment of battery recycling outlets by manufacturers, the attempt of deposit system, and the co-construction and sharing of recycling points by different manufacturers. At present, however, they are still in the exploratory phase, especially in the local pilot projects. Various incentive policies have been introduced, and different types of recycling forms have been tried respectively. Nevertheless, a unified and efficient recycling network system has not yet been developed.

\subsection{Property right restriction}

After purchasing new energy and low-speed electric vehicles, consumers are endowed with the property rights of electric vehicle batteries. In the recycling and scrapping phase, consumers still own the property rights of batteries and can dismantle and sell them by themselves, resulting in the diversification of recycling channels. Apart from maintaining the maintenance obligation, the producers do not have the property rights of power batteries, which also provides excuses for manufacturers to shirk the responsibility of recycling. Given this, some developed nations have rolled out the recycling deposit system and various recycling methods to tackle down the problem of property rights of power batteries. Moreover, several Chinese automobile enterprises are delving into the recycling mode 
of signing recycling agreements with consumers. Corresponding policies (e.g., the Broaden Producer Responsible Mechanism) require manufacturers to track the life cycle of batteries, whereas they remain in the initial stage of implementation, and the specific implementation is still being explored.

\subsection{Insufficient echelon exploitation layout}

With the arrival of "scrapping tide" of automotive power batteries, the production capacity of power batteries recycle enterprises is expanding rapidly, and there is already sign of overcapacity. As illustrated in Figure 2, the restrictive policies for the processing end of power batteries recycle are relatively complete, but there are fewer policies for the application end. At present, it is largely proposed to encourage the echelon exploitation, and the echelon exploitation enterprises are restricted to some extent. There is lack of overall market layout and incentive policies for echelon exploitation.

\section{Policy recommendations}

\subsection{Promotion of construction of top-level laws and regulations}

The leaping forward of new energy electric vehicles in China has been witnessed. At present, many nations have set a timetable for banning the sale of fuel vehicles. China is also undergoing the trend of novel energies-based vehicles replacing fuel ones. As impacted by the constraints of energy and environmental factors, the construction and improvement of the power batteries recycle industry is imminent. On the one hand, given the existing policies, according to the Broaden Producer Responsible Mechanism, the policies of each link of power batteries recycle should be refined, and the construction of power batteries recycle system should be facilitated. On the other hand, abiding by the existing policies and by complying with the overall planning, laws and regulations on power batteries recycle should be issued to optimize the rules and regulations on power batteries recycle, environmental protection and other issues, which should be elevated to the legal level.

\subsection{Acceleration of construction of recycling network}

Based on the existing Broaden Producer Responsible Mechanism and traceability management platform, the overall construction of recycling network for the electric vehicle power batteries should be accelerated, the cooperation among power battery plants, new energy automobile plants and third-party recycling enterprises around the existing power batteries recycle outlets network should be further promoted, as an attempt to promote the formation of a closed-loop power batteries recycle network. Moreover, the advanced experience of local pilot projects should be learned to ensure reasonable layout and effective operation of recycling service outlets. In addition, the construction of industrial alliance should be accelerated, and the cooperation mode between the industrial alliance and the participants should be explored based on the advanced experience of power batteries recycle system in developed nations, as an attempt to achieve win-win cooperation among all parties.

\subsection{Active promotion of deposit recycling system}

The establishment of deposit recycling system should be further promoted. The deposit recycling system should be promoted on the basis of existing policies, and efforts should be made to proactively promote electric vehicle manufacturers, automobile dealers and consumers to sign battery recycling agreements, and standardize the recycling channels of scrapped power batteries. In addition, combined with the traceability management platform, the tracking system of power battery life cycle should be improved, and more economic and efficient recycling methods should be explored, as an attempt to ensure the full life cycle management and efficient recycling of power batteries.

\subsection{Promotion of development of echelon exploitation industry}

At present, China Tower Corporation Limited, a representative enterprise of echelon exploitation in China, had installed echelon exploitation batteries in 20,000 base stations nationwide by 2019, accounting for more than 50\% of the retired batteries. It is suggested seen that the development of echelon exploitation industry is in its infancy and is still under exploration. In addition, pilot projects around the country are also proactively exploring the mode of echelon exploitation batteries. Accordingly, the government should launch targeted arrangement for the echelon exploitation industry, proactively introduce exploration and guiding policies based on existing restrictive policies, and introduce incentive and guiding policies e.g., subsidies and tax reduction according to the actual situation of different regions, as an attempt to promote rapid development of the echelon exploitation industry.

\section{Funding}

This paper is funded by the Special Research Project of Institute of Public Governance, Peking University, Project No.: YQZX202011.

\section{References}

Alliance of Technological Innovation in Compulsory Resources Recycling Industry. (2018). General Production Requirements for Overall Exploitation Enterprises of Waste Power Batteries, Technical Specifications for Wet Recovery of Lithium in Waste Lithium-ion Batteries, Crude Cobalt Nickel Solution, Crude Nickel Sulfate Solution, Industrial Molybdic Acid [EB/OL]. http://www.atcrr.org/show-19-3215-1.html

Cheng, X. (2010). Problems and countermeasures of waste batteries recycling in China. Journal of Xiamen Radio and Television University, (04), 60-62 (in Chinese). 
Dewulf, J., Van der Vorst, G., Denturck, K., Van Langenhove, H., Ghyoot, W., Tytgat, J., \& Vandeputte, K. (2010). Recycling rechargeable lithium ion batteries: Critical analysis of natural resource savings. Resources, Conservation and Recycling, 54(4), 229-234. https://doi.org/10.1016/j.resconrec.2009.08.004

Ding, H. (2016). Management experience and enlightenment of power battery recycling in the United States. Environmental Protection, 44(22), 69-72 (in Chinese).

https://doi.org/10.14026/j.cnki.0253-9705.2016.22.016

Ding, S. (2009). Research on waste battery recycling. Ecological Economy (Academic edition), (02), 385-388 (in Chinese).

Ding, X., \& Zhong, J. (2018). Power battery recycling mode selection using an extended MULTIMOORA method. Scientific Programming, 2018, 7675094.

https://doi.org/10.1155/2018/7675094

Dunn, J. B., Gaines, L., Kelly, J. C., \& Gallagher, K. G. (2016). Life cycle analysis summary for automotive lithium-ion battery production and recycling. In REWAS 2016 (pp. 73-79). Springer, Cham.

https://doi.org/10.1007/978-3-319-48768-7_11

Gaines, L., \& Singh, M. (1995). Energy and environmental impacts of electric vehicle battery production and recycling (No. ANL/ ES/CP-87281; CONF-9510282-2). Argonne National Lab., IL, United States. https://doi.org/10.4271/951865

Gao, Y., Wang, J., Zhu, F., \& Zhou, W. (2014). Research on environmental impact of vehicle power battery recycling. Automobile \& Accessories, (20), 41-43 (in Chinese).

General Administration of Quality Supervision, Inspection and Quarantine of the People's Republic of China. (2016a). Code of Automotive Power Batteries [EB/OL]. https://www.miit. gov.cn/n1146285/n1146352/n3054355/n3057585/n3057589/ c5288442/part/5288458.pdf

General Administration of Quality Supervision, Inspection and Quarantine of the People's Republic of China. (2016b). Specification and Dimension of Power Batteries for Electric Vehicles (Draft) [EB/OL]. https://www.miit.gov.cn/n1146285/ n1146352/n3054355/n3057585/n3057589/c5288442/ part/5288457.pdf

General Administration of Quality Supervision, Inspection and Quarantine of the People's Republic of China. (2017a). Specification for Recycling and Dismantling of Automotive Power Batteries [EB/OL].

http://www.china-nengyuan.com/tech/110809.html

General Administration of Quality Supervision, Inspection and Quarantine of the People's Republic of China. (2017b). Detection of Residual Energy of Automotive Power batteries recycle [EB/OL]. http://www.cqjnw.org/article.php?id=11772

General Administration of Quality Supervision, Inspection and Quarantine of the People's Republic of China. (2017c). Coding Rules for Automotive Power Batterie [EB/OL]. https://max.book118.com/html/2017/0808/126688180.shtm

General Administration of Quality Supervision, Inspection and Quarantine of the People's Republic of China. (2018). Requirements for Recycling Materials for Automotive Power Batteries (Draft) [EB/OL]. https://max.book118.com/ html/2018/0802/7103035155001141.shtm

General Office of the State Council of the People's Republic of China. (2017). Implementation Plan for Broaden Producer Responsible Mechanism [EB/OL]. http://www.gov.cn/zhengce/ content/2017-01/03/content_5156043.htm

Georgiadis, P., \& Besiou, M. (2010). Environmental and economical sustainability of WEEE closed-loop supply chains with recycling: A system dynamics analysis. The International Journal of Advanced Manufacturing Technology, 47(5-8), 475-493. https://doi.org/10.1007/s00170-009-2362-7
Halog, A., Sagisaka, M., \& Inaba, A. (2003, September 8-10). Assessment of electric vehicle battery technologies using fuzzy linguistic and AHP approaches. In $8^{\text {th }}$ International Conference on Environmental Science and Technology, (Vol. A., pp. 294-301). Lemnos Island, Greece.

Jiang, K. (2019). Research on the recycling of power batteries of new energy vehicles based on echelon use. Chinese Labat Man, (02), 51-54+96 (in Chinese).

https://doi.org/10.16679/j.cnki.21-1121.2019.02.001

Jungst, R. G. (1997). Recycling readiness of advanced batteries for electric vehicles (No. SAND-97-2343C; CONF-971096-). Sandia Corp., Albuquerque, NM, United States.

Li, J. (2010). Current situation analysis and improvement countermeasures of waste battery recycling mode. Oriental Enterprise Culture, (05), 237 (in Chinese).

Li, M., Wu, J., \& Wang, C. (2008). Current situation of waste battery treatment and management countermeasures. China Science and Technology Information, (09), 19-20 (in Chinese).

$\mathrm{Li}, \mathrm{W}$. (2018). Research on reverse logistics network optimization of power battery [Master's thesis]. North China Electric Power University Beijing (in Chinese). https://kns.cnki.net/ KCMS/detail/detail.aspx?dbname=CMFD201901\&filena $\mathrm{me}=1018240798 . \mathrm{nh}$

Li, Y., \& Gao, Y. (2013). Experience and enlightenment of power battery recycling in Germany. Resource Recycling, (10), 48-50 (in Chinese).

Liu, J., Cai, G., \& Liu, H. (2012). Research on agent-based battery recycling model for electric vehicles. Logistics Technology, (15), 298-301+310 (in Chinese).

Ministry of Ecology and Environment of the People's Republic of China. (2016). Policies on Prevention and Control Technology for Waste Battery Pollution (Draft)[EB/OL]. http://www.mee. gov.cn/gkml/hbb/bgth/201602/t20160219_330434.htm

Ministry of Industry and Information Technology of the People's Republic of China. (2015). Industry Standard Conditions for Automotive Power Batteries [EB/OL].

http://www.china-nengyuan.com/news/75011.html

Ministry of Industry and Information Technology of the People's Republic of China. (2016a). Industry Standard Conditions for Overall Exploitation of Waste Power Batteries of Novel energiesbased vehicles [EB/OL]. https://www.miit.gov.cn/n1146295/ n1146592/n3917132/n4061768/c5153417/part/5153446.pdf

Ministry of Industry and Information Technology of the People's Republic of China. (2016b). Interim Measures for Management of Industry Standard Announcement for Overall Exploitation of Waste Power Batteries of Novel energies-based vehicles [EB/OL]. http://www.china-nengyuan.com/news/91887.html

Ministry of Industry and Information Technology of the People's Republic of China. (2016c). Interim Measures for Power batteries recycle of Novel energies-based vehicles (Draft)[EB/OL]. http://www.china-nengyuan.com/news/101746.html

Ministry of Industry and Information Technology of the People's Republic of China. (2018a). Interim Measures for Management of Power batteries recycle of Novel energies-based vehicle [EB/OL]. http://www.huaibin.gov.cn/wzd/webinfo/2018/08/1534706988493194.htm

Ministry of Industry and Information Technology of the People's Republic of China. (2018b). Implementation Plan for Pilot Projects of Power batteries recycle of Novel energies-based vehicles [EB/OL]. http://www.gov.cn/xinwen/2018-07/26/content_5309433.htm

Ministry of Industry and Information Technology of the People's Republic of China. (2018c). Interim Provisions on Traceability 
Management of Power batteries recycle of Novel energies-based vehicles $[\mathrm{EB} / \mathrm{OL}]$.

http://www.law-lib.com/law/law_view1.asp?id=627675

Ministry of Industry and Information Technology of the People's Republic of China. (2019a). Discharge Specifications for Automotive Power batteries recycle [EB/OL].

http://www.doc88.com/p-37016948572835.html

Ministry of Industry and Information Technology of the People's Republic of China. (2019b). Automotive Power batteries recycle and Echelon exploitation Product Identification [EB/OL]. http://std.samr.gov.cn/gb/search/gbDetailed?id=5DDA8B9D C38918DEE05397BE0A0A95A7

Ministry of Industry and Information Technology of the People's Republic of China. (2019c). Guideline for Construction and Operation of Recycling Service Outlets of Power Batteries of Novel energies-based vehicles (Draft) [EB/OL].

https://baijiahao.baidu.com/s?id=1644355147492280220\&wf $\mathrm{r}=$ spider\&for $=\mathrm{pc}$

Ministry of Industry and Information Technology of the People's Republic of China. (2020). Industry Standard Conditions for Overall Exploitation of Waste Power Batteries of Novel energies-based vehicles (2019 version)[EB/OL]. http://gxt.jl.gov.cn/ $\mathrm{xxgk/zcwj/bwgz/202001/t20200115 \_ 6543115.html}$

Ministry of Industry and Information Technology of the People's Republic of China. (2019d). Interim Measures for Industry Standard Announcement Management of Overall Exploitation of Waste Power Batteries of Novel energies-based vehicles (2019 version) [EB/OL]. http://gxt.jl.gov.cn/xxgk/zcwj/ bwgz/202001/t20200115_6543115.html

National Development and Reform Commission of the People's Republic of China. (2016). Policies on Recycling Technologies for Electric Vehicle Power Batteries (2015 edition) [EB/OL]. https://www.ndrc.gov.cn/xxgk/zcfb/gg/201601/ t20160128_961147.html

Natkunarajah, N., Scharf, M., \& Scharf, P. (2015). Scenarios for the return of lithium-ion batteries out of electric cars for recycling. Procedia CIRP, 29, 740-745.

https://doi.org/10.1016/j.procir.2015.02.170

Olofsson, Y., \& Romare, M. (2013). Life cycle assessment of lithium-ion batteries for plug-in hybrid buses [Master's thesis]. Chalmers University of Technology, Gothenburg, Sweden. https://publications.lib.chalmers.se/records/fulltext/180166/180166.pdf

Sun, B., Su, X., Wang, D., Zhang, L., Liu, Y., Yang, Y., Liang, H., Gong, M., Zhang, W., \& Jiang, J. (2020). Economic analysis of lithium-ion batteries recycled from electric vehicles for secondary use in power load peak shaving in China. Journal of Cleaner Production, 276, 123327.

https://doi.org/10.1016/j.jclepro.2020.123327

Tian, X., Wu, Y., Hou, P., Liang, S., Qu, S., Xu, M., \& Zuo, T. (2017). Environmental impact and economic assessment of secondary lead production: Comparison of main spent leadacid battery recycling processes in China. Journal of Cleaner Production, 144, 142-148.

https://doi.org/10.1016/j.jclepro.2016.12.171

The State Council of the People's Republic of China. (2012). Development Plan for Energy-Saving and Novel energies-based vehicle Industry (2012-2020) [EB/OL].

http://www.nea.gov.cn/2012-07/10/c_131705726.htm
The State Council of the People's Republic of China. (2014). Given the Guidelines of the General Office of the State Council for Expediting Novel energies-based vehicle Promotion and Application [EB/OL]. http://www.gov.cn/zhengce/content/2014-07/21/content_8936.htm

Van den Bossche, P., Vergels, F., Van Mierlo, J., Matheys, J., \& Van Autenboer, W. (2006). SUBAT: An assessment of sustainable battery technology. Journal of Power Sources, 162(2), 913-919. https://doi.org/10.1016/j.jpowsour.2005.07.039

Väyrynen, A., \& Salminen, J. (2012). Lithium ion battery production. The Journal of Chemical Thermodynamics, 46, 80-85. https://doi.org/10.1016/j.jct.2011.09.005

Wang, B. (2019). Research on Hybrid Channel recycling Pricing of Power Batteries of New Energy Vehicles under Government Subsidies [Master's thesis], Shanghai Jiao Tong University (in Chinese). https://kns.cnki.net/KCMS/detail/detail.aspx?dbna $\mathrm{me}=\mathrm{CMFD} 202001 \&$ filename $=1020805434 . \mathrm{nh}$

Wang, C., Jiang, T., \& Jiang, B. (2018). Research progress and prospect of waste power battery recycling. Recyclable Resources and Circular Economy, (10), 32-35 (in Chinese).

Xie, Y., Yu, H., Ou, Y., \& Li, C. (2015). Research on environmental impact assessment of waste power battery recycling. Inorganic Salt Industry, (04), 43-46+61 (in Chinese).

Xie, Y., Yu, H., Ou, Y., \& Li, C. (2017). Research on business model of power battery recycling. Chinese Journal of Power Resources, (04), 644-646 (in Chinese).

Xie, Y., Zhang, T., Tang, J., Yu, H., \& Ou, Y. (2019). Research on the construction of waste power battery recycling system. Environmental Science and Management, (06), 169-173 (in Chinese).

Yao, H., Wang, Y., \& Huang, J. (2015). Mode of new energy automotive battery reclamation with restriction of extender producer responsibility. Science and Technology Management Research, 35(18), 84-89 (in Chinese).

Zackrisson, M., Avellán, L., \& Orlenius, J. (2010). Life cycle assessment of lithium-ion batteries for plug-in hybrid electric vehicles-Critical issues. Journal of Cleaner Production, 18(15), 1519-1529. https://doi.org/10.1016/j.jclepro.2010.06.004

Zhang, G., Liu, S., \& Song, J. (2019). Research on power battery recycling mode of new energy vehicles. Technology and Economic Guide, (06), 102-103+99 (in Chinese).

Zhang, L., Liu, Z., \& Wang, J. (2013). Comparative analysis of life cycle environmental impacts of power systems of electric and internal combustion engine vehicles. Chinese Journal of Environmental Science, (03), 931-940 (in Chinese). https://doi.org/10.13671/j.hjkxxb.2013.03.040

Zhang, Z., \& Wu, Z. (2018). Study on recycling policies and recycling of waste power batteries. Guangzhou Chemical Industry, (03), 132-135 (in Chinese).

Zhou, J., \& Zhang, S. (2011). Analysis of legislative measures for the recycling of waste batteries in China. New West China (Late third of the month. Theoretic edition), (03), 123-124 (in Chinese).

Zhu, G., Liu, S., Hai, B., \& Chen, X. (2015). Research status of power battery recycling and cascade utilization. Power Supply Technology, (07), 1564-1566 (in Chinese).

Zhu, X., \& Li, W. (2020). The pricing strategy of dual recycling channels for power batteries of new energy vehicles under government subsidies. Complexity in Economics and Business, 2020, 3691493. https://doi.org/10.1155/2020/3691493 